\title{
Editorial
}

\section{Muito a comemorar e mais ainda a percorrer}

Dezembro de 2011!

Esse final de ano os fonoaudiólogos comemoram 30 anos de regulamentação da profissão. Um caminho marcado por conquistas e avanços conseguidos sempre com muita garra e vontade de crescer.

Esse crescimento pode ser visto em vários seguimentos, tanto no âmbito acadêmico como na esfera profissional, fundamentado em ambos os casos pelo respaldo científico de nossa profissão.

O profissional fonoaudiólogo encontra-se hoje inserido em instituições públicas e particulares; de forma isolada, em grandes equipes interdisciplinares e em empresas diversas; com atuação em diagnóstico fonoaudiológico, aprimoramento e reabilitação; em saúde pública; em gestão empresarial; na política; entre outros. Afinal um bom comunicador faz toda a diferença!

No âmbito acadêmico o crescimento é evidenciado por programas de graduação e de pós-graduação cada vez mais envolvidos com a formação profissional e comprovação científica de nosso valor. Multiplicam-se os pesquisadores com reconhecimento nacional e internacional.

O número de trabalhos científicos, o interesse por eles, o número crescente de pesquisadores distribuídos por todo o país e principalmente a diversidade dos temas que vêem sendo desenvolvidos são demonstrados pelo número de submissões de artigos e pela variada distribuição geográfica desses

Nosso crescimento também é constatado em nossos congressos, cada vez maiores, mais relevantes e mais densos. Faltam horas nos dias de Congresso para tantas atividades importantes e tantas informações relevantes. Esse ano a Sociedade Brasileira de Fonoaudiologia abordou o tema "Publicações na América Latina" em Simpósio de Atualização durante o $19^{\circ}$ Congresso Brasileiro e $8^{\circ}$ Internacional de Fonoaudiologia ocorrido em São Paulo, no qual a Revista CEFAC teve a grata oportunidade de participar. $\mathrm{Na}$ ocasião tivemos a oportunidade de verificar o interesse dos fonoaudiólogos pela produção e divulgação científica expresso pelo grande número de participantes assistindo ao Simpósio. As conferências mostraram um panorama real de nossa produção e nossos desafios como editores científicos.

A Revista CEFAC continua hoje nesses caminhos desafiadores: no ajuste contínuo da Revista, na busca por novas indexações, no empenho em conseguir manter o interesse dos autores e dos leitores, na excelência de seu Corpo Editorial, no agradecimento pelo empenho de seu Conselho Editorial e de seus pareceristas consultivos.

Além dos 120 artigos distribuídos em seis revistas publicadas nesse ano, tivemos a colaboração de grandes profissionais na elaboração dos editoriais da Revista. Cada um deles ofereceu ao leitor um enfoque que pôde mostrar um pouco das preocupações, metas, desafios e ganhos em nossa área.

Numa breve síntese desses editoriais poderemos apontar alguns itens que ilustram nossos caminhos.

Escutar, reconhecer os sons para depois transformá-los em pensamento, e devolver uma mensagem para outra pessoa é tão corriqueiro que nem paramos para pensar que esta é a Base da Comunicação', não apenas pela sua indiscutível competência técnica, mas, sobretudo, por sua humanidade². A comunicação mantém e anima a vida, compartilha idéias e reforça o sentimento de pertencimento 2 . A Fonoaudiologia, mais que uma Ciência, está voltada ao Humano e o conceito da inclusão e da prática da diversidade não deve estar só nas leis e livros pedagógicos, mas devem estar na prática, dentro de nós ${ }^{1}$. É difícil aceitar que um paciente não receba atendimento, pelo fato do trabalho de Fonoaudiologia não ser considerado necessário, ou ainda, por não possuir "evidência científica" da sua eficiência e eficácia ${ }^{3}$. É necessário comprovar que o que é realizado tem grande valor, e que faz diferença na vida do usuário ${ }^{3}$. Nesse sentido, a busca pela objetividade no diagnóstico leva o profissional da área de comunicação humana a desejar cada vez mais recursos avançados que possibilitem a comprovação do que é observado na avaliação clínica ${ }^{4}$ e para isso contamos hoje com tecnologia auxiliando a pesquisa e facilitando buscas- é um verdadeiro universo de informações à nossa frente ${ }^{5}$. Recentemente a profissão de Fonoaudiólogo recebeu uma ajuda cinematográfica quando o filme "O Discurso do Rei" colocou a profissão nas telas de cinema ${ }^{3}$. Porém, devemos continuar desenvolvendo estudos, os quais mostrem nosso valor em diagnóstico e enfoquem mudanças de qualidade de vida decorrentes do tratamento fonoaudiológico ${ }^{3}$. A meta de todo fonoaudiólogo hoje, em qualquer país, deve ser provar, via ciência, que a sua intervenção é, de fato, eficaz ${ }^{3}$. 
É nesse sentido que a Revista CEFAC apresenta seu sexto fascículo do ano de 2011. São vinte artigos científicos que trazem suas contribuições para a comunidade científica, para os clínicos e para a sociedade. Estamos mostrando nossa produção e nosso valor.

Parabéns a todos e que os próximos anos de nossa profissão sejam ainda mais promissores.

Boa leitura!

Esther Mandelbaum Gonçalves Bianchini

Editora Científica Revista CEFAC

\section{REFERÊNCIAS BIBLIOGRÁFICAS}

1. Cotes Cláudia. Direitos mais humanos. Rev. CEFAC [periódico na Internet]. 2011 Out [citado 2011 Dez 09]; 13(5): 781-782. Disponível em: http://www.scielo.br/scielo.php?script=sci_arttext\&pid=S1516$18462011000500001 \&$ lng=pt. http://dx.doi.org/10.1590/S1516-18462011000500001.

2. Weinstein Monica Cristina Andrade. Fonoaudiologia e empreendedorismo. Rev. CEFAC [periódico na Internet]. 2011 Fev [citado 2011 Dez 09]; 13(1): 07-07. Disponível em: http://www.scielo.br/scielo.php?script=sci_arttext\&pid=S1516-18462011000100001\&lng=pt. http://dx.doi. org/10.1590/S1516-18462011000100001.

3. Santini Celia Salviano. "O Discurso do Rei" ou O Futuro da Fonoaudiologia. Rev. CEFAC [periódico na Internet]. 2011 Jun [citado 2011 Dez 09]; 13(3): 397-397. Disponível em: http://www.scielo.br/scielo.php?script=sci_arttext\&pid=S1516-18462011000300001\&lng=pt. http://dx.doi.org/ 10.1590/S1516-18462011000300001.

4. Silva Hilton Justino da. O limite entre a experiência clínica e o uso de tecnologia em saúde da comunicação humana. Rev. CEFAC [periódico na Internet]. 2011 Ago [citado 2011 Dez 09]; 13(4): 591-591. Disponível em: http://www.scielo.br/scielo.php?script=sci_arttext\&pid=S1516-18462011000400001\&lng=pt. http://dx.doi.org/10.1590/S1516-18462011000400001.

5. Bianchini Esther Mandelbaum Gonçalves. Editorial. Rev. CEFAC [periódico na Internet]. 2011 Abr [citado 2011 Dez 09]; 13(2): 7-7. Disponível em: http://www.scielo.br/scielo.php?script=sci_arttext\&pid=S1516$18462011000200001 \&$ lng=pt. http://dx.doi.org/10.1590/S1516-18462011000200001. 